\title{
Impact of climate change and ongoing adaptation measures in The Bangladesh Sundarbans
}

\author{
Suprakash Chakma1, Anup Kumar Paul², Md. Arifur Rahman ${ }^{3}$, Mahmudul Hasan Mithun ${ }^{4}$, Atiqur \\ Rahman Sunny ${ }^{5,6^{*}}$ \\ ${ }^{1}$ Department of Fisheries Technology, Patuakhali Science and Technology University, Bangladesh \\ ${ }^{2}$ Chhuya Agro Products Ltd, Bangladesh \\ ${ }^{3}$ Department of Fisheries Biology \& Genetics, Patuakhali University of Science and Technology, Bangladesh \\ ${ }^{4}$ Department of Fisheries Biology and Aquatic Environment, Bangabandhu Sheikh Mujibur Rahman Agricultural \\ University, Gazipur-1706, Bangladesh, \\ ${ }^{5}$ Department of Genetic Engineering and Biotechnology, Shahjalal University of Science and Technology, Bangladesh \\ ${ }^{6}$ Suchana Project, WorldFish, Bangladesh Office, House\# 22B, Road\# 07, Block-F, Banani, Dhaka, Bangladesh
}

\begin{abstract}
The climate of Bangladesh has changed drastically which may put considerable adverse impacts on mangrove fishers but very few studies focused on this professional group. An attempt was made to perceive the impact and adaptation measures of the Sundarbans mangrove resource users, employing interviews and focus group discussions. A total of 150 respondents were randomly selected from the Sundarbans west under Shyamnagar Upazila of Satkhira District. It was revealed that the abundance of fishes, fuel woods, honey, golpata (Nypa fruticans), and shrimp post-larvae (PL) was reduced considerably. The resource users have adapted themselves by changing their occupation and becoming jobless and depending on the other family members. PL collection, honey collection, shrimp culture, and wood collection were found professional adapting strategies to adopt cyclone, flood, salinity intrusion, river erosion, and drought. Several recommendations are elicited, the implementation of which is important to ensure livelihood sustainability of the mangrove communities.
\end{abstract}

Keywords: Sundarbans, Fisheries, Natural disasters, Occupational changes, Climate change.

\author{
Corresponding author: \\ Atiqur Rahman Sunny \\ Dept. of Genetic Engineering and Biotechnology, Shahjalal University of Science and \\ Technolohy, Sylhet, Bangladesh \\ Researcher (FDO), WorldFish, Bangladesh Office. \\ Email:atiksunny@yahoo.com
}




\section{Introduction}

The Sundarbans is a part of the world's largest delta formed by the rivers the Ganges, Brahmaputra, and Meghna, covers about $4.2 \%$ of the total Bangladesh where forests cover only $10.2 \%$ of the land area $^{1,2}$. It is the largest single block of tidal halophytic mangrove forest in the world ${ }^{1,2}$ which is situated in the South-West area $\left(21^{\circ} 31^{\prime}-22^{\circ} 38^{\prime} \mathrm{N}\right.$ and $\left.89^{\circ} 00^{\prime}-89^{\circ} 55^{\prime} \mathrm{E}\right)$ of Bangladesh and has been a Ramsar site from 1992, world heritage of UNESCO from $1997^{2,3}$.

It has covered approximately 10,000 km², among which 60 percent remain in Bangladesh and the rest of the part remain in India ${ }^{4,5}$. The Sundarbans covers approximately $6,017 \mathrm{~km}^{2}$ area in Bangladesh, where $4143 \mathrm{~km}^{2}$ area is landmass and remaining $1874 \mathrm{~km}^{2}$ area are water bodies in forms of a network of rivers, canals, and creeks ${ }^{6}$. Sathkhira, Khulna, and Bagherhat districts cover approximately $99 \%$ of the Sundarbans in our country and the remaining areas are in Patuakhali and Barguna districts ${ }^{7}$. Three types of ecosystem services are primarily derived from the Sundarbans of Bangladesh. These include provisioning services (benefits that people obtain directly, e.g., timber and food products such as fish), cultural services (non-material benefits, e.g., mangrove tourism), and regulatory services (benefits obtained from the regulation of ecosystem processes, e.g., carbon sequestration and protection from cyclones) ${ }^{2}$. The Sundarbans mangrove forest is rich with its natural floral and faunal diversity like 334 species of plants, 425 species of wildlife; including 40 species of mammals, 300 species of birds and 35 species of reptiles, 177 species of fish, 24 species of shrimp, and 7 species of crabs, etc. ${ }^{2,6,8}$. About 5 million people are engaged directly and indirectly which are depending on the Sundarbans for their livelihoods where $69 \%$ are involved with the aquatic resources, $22 \%$ people are with the collection of wood resources; $5 \%$ are involved with the non-timber forest product, and $4 \%$ are involved with other purposes $^{9}$.

The Sunderbans provides a wonderful aesthetic attraction for local and foreign tourists. The vegetated tidal lands of the Sundarbans also function as an essential habitat, produce nutrients, and purifies water. The forest also traps nutrients and sediment, acts as a storm barrier, shore stabilizer, and energy storage unit. Mangrove wetlands act as a barrier against natural climates, avoid coastal erosion and provide nursery grounds for a number of commercially important fish, prawns, and crabs. Some of these mangrove wetlands play an important role in enhancing the fishery production of the adjacent neritic waters by exporting organic and inorganic nutrients ${ }^{10}$. The environmental setting of this multiple-use ecosystem is governed by physical forces such as 
geomorphology of the coast, climate, tidal amplitude and duration, and quantity of freshwater inflow ${ }^{11-14}$.

Categorized as "Reserved Forest" the Sundarbans is very important for being the source of forestry products and fish that enrich the local and national economy, as well as for being the protector from the heavy ravages of periodical cyclones and tidal surges originating from the sea ${ }^{15-17}$. At present four major types of livelihood activities are practiced in the coastal areas including mangrove forests this are agriculture, fishery, wood collection, and honey collection ${ }^{18-20}$. Approximately $65 \%$ of the total population is dependent on agriculture-based economy. Fishing activities are prevalent at various scales in the Sundarbans catering to livelihoods amongst $15 \%$ of the population. Organized large scale fishing activity occurs in the sea and deep water and small scale fishing activity in the delta region (half of them are illegal) ${ }^{21-24}$. Microscale fishing activity in the shallow river bed is operated mainly to collect the prawns/shrimps post-larvae $\mathrm{e}^{25-28}$.

Climate change due to global warming is predicted to cause an annual temperature rise of 0.4 degrees celsius in Bangladesh and resulting in sea level is also predicted to rise by 4 millimeters every year ${ }^{2,16,29-31}$. These phenomena will result in an increase in salinity and a decrease in the sweet water flow in the Sundarbans and hence will destroy major forest resources ${ }^{32-34}$. Climate change creates resource shortages and unreliable job markets that lead to the increased migration ${ }^{35-}$ 37. Several studies have been conducted on Sundarbans mangrove forest but the limited study has been conducted on the climate change impact of Sundarbans. Considering the above factors, therefore the present study has been conducted to identify the impact of climate change on the Sundarbans mangrove forest and adaptation measures taken by resource users of Sundarbans.

\section{Methodology}

The study area covered Sundarbans west in Shyamnagar Upazila of Satkhira district. The study was conducted for a period of nine (9) months from July 2017 to March 2018. There were a total of 150 respondents from different socio-economic and operational groups (fishermen, honey collectors, golpata collectors, wood-cutter, and resource harvesters). As a method of carrying out a successful interview, the respondents were interviewed with semi-structured questionnaires designed for these purposes. The purpose of the survey was to gather information related to demography (e.g., basic information of community), depression and cyclones (duration, types of disaster, frequency/wind speed, storm surge height, and casualty), and mortality rate. The survey 
method was followed for collecting both quantitative and qualitative primary data from each spot using a well defines and pre-tested questionnaire following the objectives set for the study. Secondary data were collected from different GO's such as the Bangladesh Bureau of statistics (BBS), Upazila Fisheries Officer (Shyamnagar), Bangladesh forest department, NGO's like BRAC, Prodipan, DSK, Practical Action, Shushilon, and DFID (Department for International Development). Descriptive statistics were derived to summarize the property of the data set, and the analysis was conducted through the usage of SPSS version 16.0 (statistical package for social science) and MS Excel.

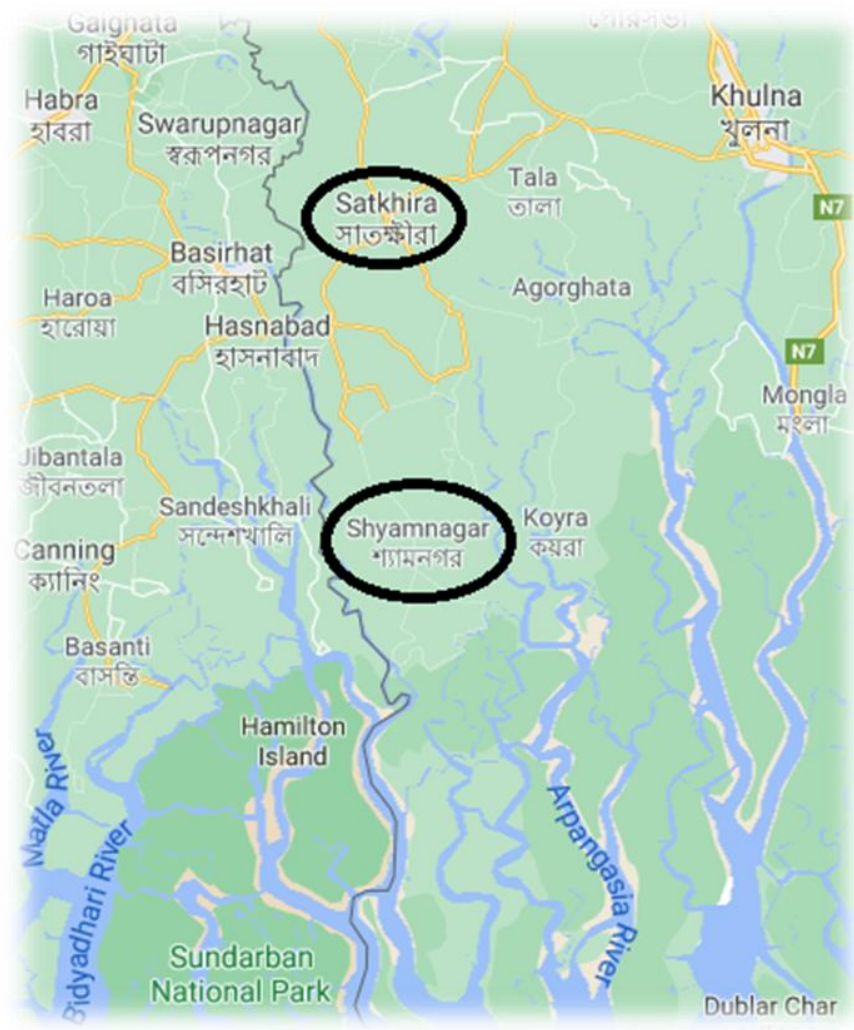

Fig. 01. Location of the study areas.

\section{Results and Discussion}

\subsection{Climate changing hazards}

The respondents were interviewed to know about 30 year's climate-changing hazards which were shown in Figure 2. Respondents have faced cyclone (34\%), flood (6\%), drought (1\%), river erosion (2\%), salinity intrusion (5\%), and 52\% faced multiple hazards (such as cyclone, flood, salinity intrusion etc.). The majority of them had been faced cyclones, floods, salinity intrusion, drought, 
river erosion etc. A study revealed that most of the respondents had faced tidal surges, floods, and cyclones $(91.67 \%, 66.67 \%$, and 50\%, respectively). River erosion, tsunami, and excessive rainfall were the other disasters faced by the respondents. The natural disaster was the constant company of the coastal population. They were faced more than one disaster every year ${ }^{21,37}$. The disaster was considered to be a great constraint for sustainable development in Bangladesh. Cyclone, tidal surge, flood, river bank erosion were some of the worst types of the disaster which was badly affecting the livelihood of our people especially in the coastal zone ${ }^{22,38}$. Coastal areas put the coastal peoples at high risks as these areas were susceptible to numerous natural hazards, such as cyclones, tidal surges, salinity intrusion, riverbank erosion, shoreline recession, tsunami etc ${ }^{39}$. The risks from tropical cyclones, storm surges, floods, and other climatic hazards are geographically concentrated in specific regions of the Sundarban ${ }^{25,37}$.

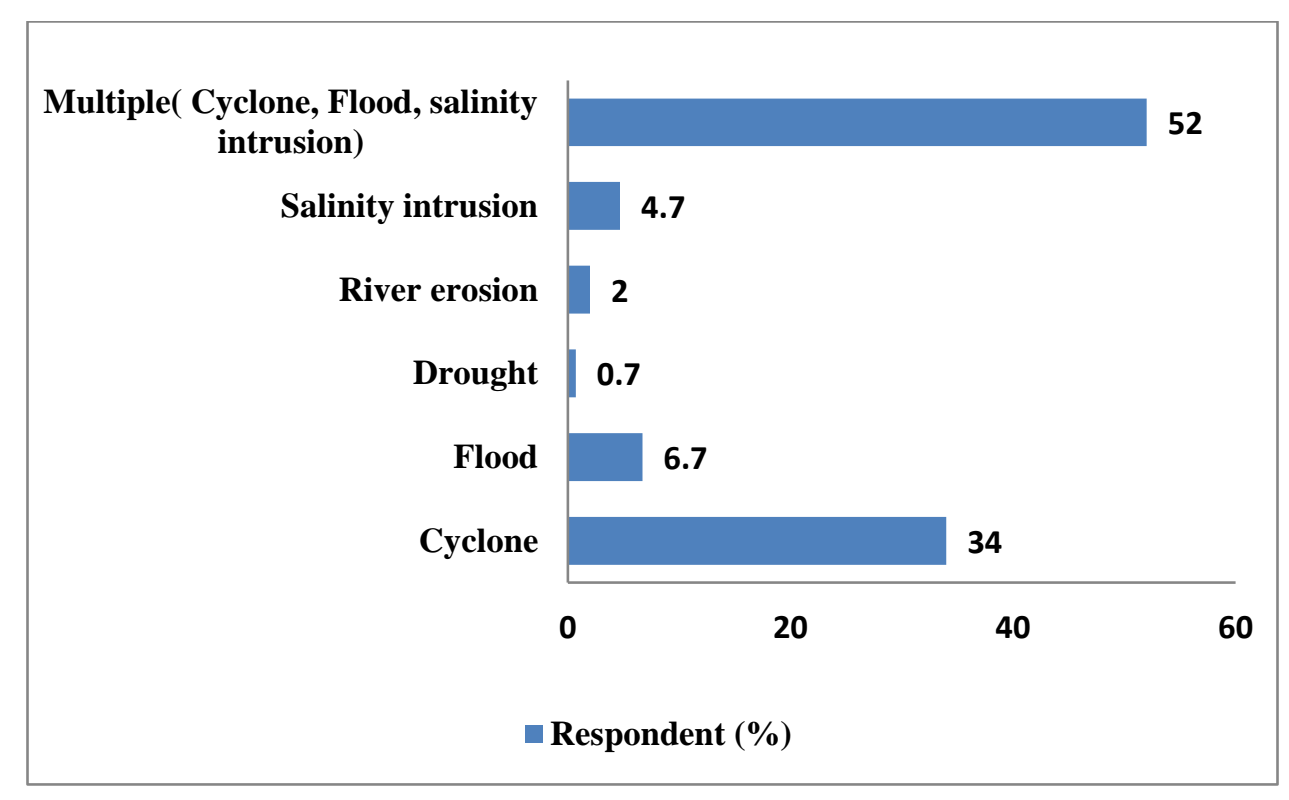

Fig. 02. Climate change hazards of Sundarban.

\subsection{Devastating natural disasters}

The frequent occurrence of extreme events such as cyclones, strong wind, and wave, current and tidal surges made the livelihood of the fishers more vulnerable. The major adverse climatic condition included flood and the tidal surge in 1985, a devastating cyclone in 1991, flood in 1987 , 1998, 2004, and 2007, cyclone Sidr in 2007, Rashmi in 2008, Aila, Nargis and Bijli in 2009, 
Mahasen in 2013 and Gorki in 2016 that put adverse impact on the communities by destroying their residence and fishing utensils and allured to illegal fishing to compensate the loss ${ }^{37,38}$. The disasters which affected mostly were represented in Table 1. Most of the respondents (39.3\%) reported that Aila of 2009 was more dangerous, $22 \%$ reported Sidr of 2007, $18 \%$ reported cyclone of 1988, 15\% reported a flood of 1998, 4.7\% reported cyclone of 1996 and $1 \%$ reported cyclone of 1991. Respondents mentioned that cyclone Aila was hitting at night; maximum people had no news about this disaster so it damaged a lot, man, animals, birds were destroyed at a large scale. During 1991-2000, 93 major disasters were recorded in Bangladesh ${ }^{26}$. The impacts of climate change affected badly to the coastal community. The coastal community of Bangladesh first felt in 1970 and 1991, when two super cyclones hit the country and caused the death of about 500,000 and 138,000 people, respectively ${ }^{38,40,41}$. In Bangladesh, the south-west part of the country was affected by category 4 Cyclone, Cyclone Sidr, in November $2007^{37,38}$. Cyclone Aila began as a disturbance on 21 May in the Bay of Bengal, strengthened as a category 1 cyclone, caused the death of about 200 people, and left hundreds of thousands more homeless ${ }^{25}$.

Table 1: Experience of the people with dangerous disasters

\begin{tabular}{lll}
\hline Year of Disaster occurrence & $\begin{array}{l}\text { No. } \\
\text { respondents }\end{array}$ & $\begin{array}{l}\text { Respondents } \\
(\boldsymbol{\%})\end{array}$ \\
\hline $24-27$ November, 1988 & 27 & 18.0 \\
April, 1991 & 1 & 1 \\
1996 & 7 & 4.7 \\
$19-22$ November, 1998 & 23 & 15 \\
15 November, 2007 (Sidr) & 33 & 22 \\
27 May, 2009 (Aila) & 59 & 39.3 \\
\hline Total & 150 & 100.0 \\
\hline
\end{tabular}

\subsection{Damages of natural disasters}

The present study found that respondents experienced the death of people (2\%), house damage and death of domestic animals (35\%), damage of crop (15\%), damages of fisheries $(23 \%)$, death of man, animal, and house damage (13\%), and (12\%) was damage of fish and crops (Figure 3). 
Natural disasters drastically destroyed houses, trees, roads, dams, causing the death of man, animals, birds, and damaged fish farms, croplands.

Koyra, Dacope, and Shymnagar Upazila of the south-west coastal belt of Bangladesh were hit the hardest by the cyclone Aila. The storm surge washed away all the houses, crops and agricultural land, homestead garden, and livestock, and thereby the area experienced huge toll damages to lives and livelihoods. Aila not only broke down the overall social harmonization but also resulted in a chaotic situation in those areas. One-fourth of the Sundarbans forest area had been damaged by the cyclone Sidr ${ }^{2,26,38}$. Precisely eight to ten percent of the forest had been damaged completely, while fifteen percent has been partly damaged.

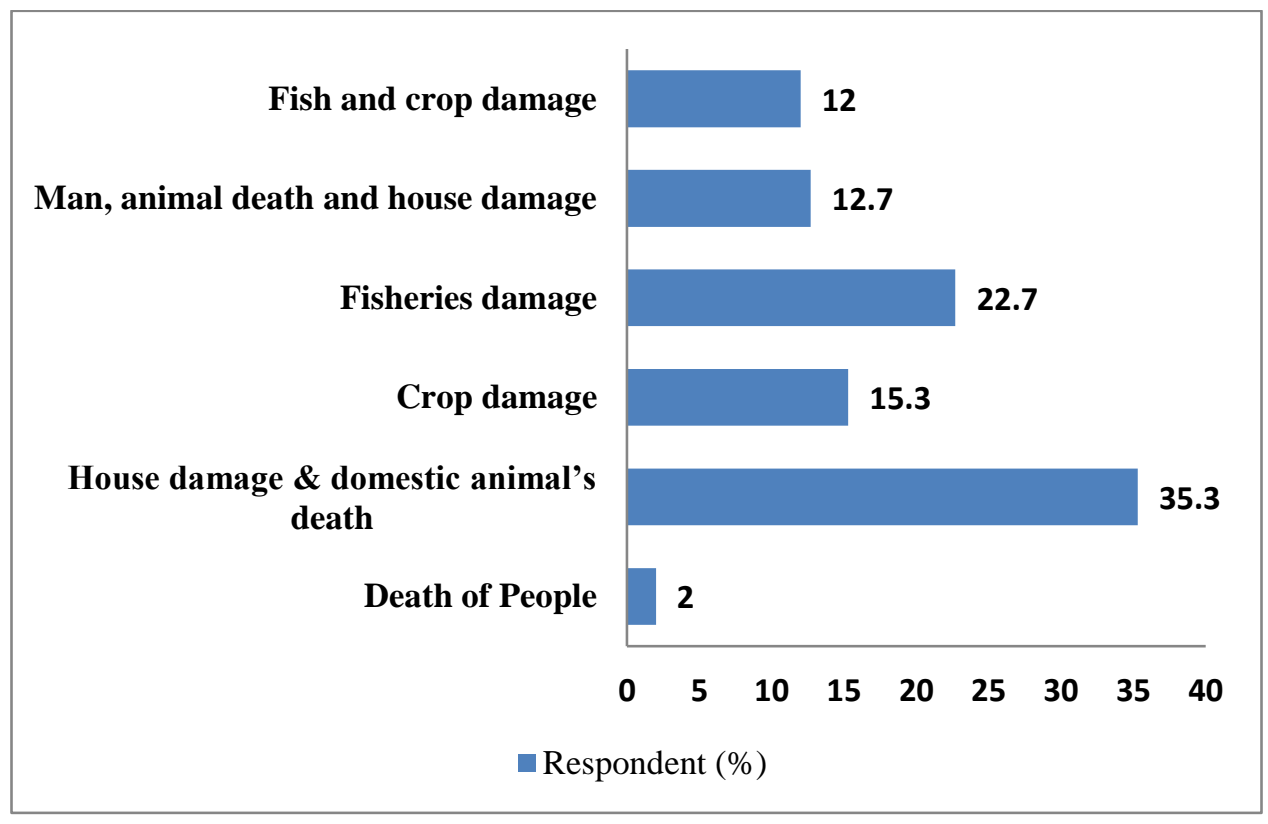

Fig. 03. Damages of natural disasters in the coastal regions.

\subsection{Resources of the Sundarbans before frequent occurrence of natural calamities}

In the present study, it was found that $34 \%$ of resource users remarked plenty of fish, crab, and shrimp, $21 \%$ remarked plenty of fruits, $12 \%$ remarked plenty of livestock and wild animals, $4 \%$ remarked plenty of river and canal, 11\% remarked availability of honey and wax, and 18\% remarked plenty of golpata (Figure 4). Sundarbans, the largest mangrove forest was teeming with natural resources and were served as a diverse habitat for many species, including fish, birds, reptiles, amphibians, mollusks, crustaceans, and many other invertebrates. It was full of Sundari trees (Heritiera fomes). The leaves of golpata (Nipa fruticans) were harvested by the local community for thatching purposes. Mangroves were a good source of wood, timber, and housing 
materials, firewood, charcoal, and poles for fish traps. Mangrove was a source of honey and wax, which had high economic value ${ }^{2}$. The vegetated tidal lands of the Sundarbans also functioned as an essential habitat, produce nutrients and purify water. The forest also traps nutrients and sediment, acts as a storm barrier, shore stabilizer, and energy storage unit. The Sundarbans ecosystem supported rich fisheries diversity ${ }^{2,37}$.

This ecosystem supported 27 families and 53 species of pelagic fish, 49 families and 124 species of demersal fish, 5 families and 24 species of shrimps, 3 families and 7 species of crabs, 8 species of lobster ${ }^{2,37}$. A total of 334 plants, 165 algal, 13 special orchids, 17 ferns, 87 monocotyledons, and 230 dicotyledons belonging to 245 genera and 75 families from the Sundarbans and adjacent area were found available ${ }^{27}$. The principal tree species was Sundry (Heritiera fomes) which covers about $73 \%$ of the total landmass and the second species was Gewa (Excoecaria agallocha) which covered about $16 \%$ of the total forest area. The plant species included 35 legumes, 29 grasses, 19 sedges, and 18 euphorbias. Among 50 true mangrove plant species recorded throughout the world, the Sundarbans alone contain 35 species. The magnificent among the animals on land were Royal Bengal Tiger, spotted deer, barking deer, and wild boars were there in plenty. Besides those jungle cats, fishing cats, civet cat, monkey, bengal fox, jackle, water monitor, monitor lizard and snakes were important faunal spp. Moreover, abundant of the Sundarbans were purple heron, pond heron, cattle egret, little egret, open billed stork, smaller adjutant stork, brahmini kite, spotted dove, roseringed parakeet, crow pheasant, woodpecker, bee-eater, drongo, pide myna, jungle myna, bulbul, tailorbird, magpie robin, sparrow etc., Otherwise, recorded that wild Buffalo, 2 species of deer, javan rhinoceros extinct and presently 2 species of amphibians, 14 species of reptiles 25 species of birds and 5 species of mammals were considered as endangered species. This paper was to produce a new assessment of the ecology of the mangrove of Sundarbans ${ }^{27}$. 


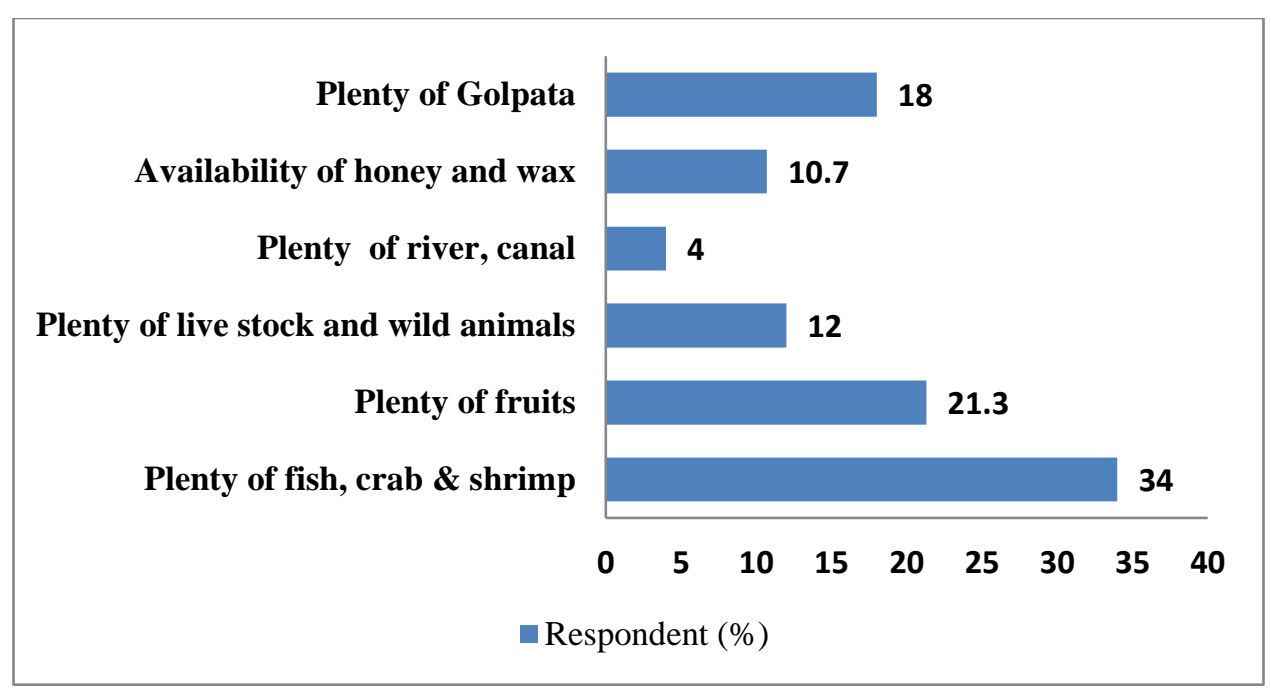

Fig. 04. Resources of the Sundarbans with less impact of climate change.

\subsection{Resources of the Sundarbans after frequent occurrence of natural calamities}

The resource users remarked that inadequacy of fish, crab, and shrimp (29\%), scarcity of wooden tree $(23 \%)$, scarcity of animals $(13 \%)$, reduction of honey and wax (9\%), and $26 \%$ found scarcity of golpata (Figure 5). Climate change reduced the stock of resources. Saline water increased with the sea level rising, as a result, freshwater fishes losses their habitat. One calculation showed that a $25 \mathrm{~cm}$ sea level rise would result in a $40 \%$ mangrove loss ${ }^{28}$. The local community remarked that excessive heat reduced the water retention capacity of the land, trees have died lack of water. The rain did not come in timely so animals, fishes cannot breed, as result fishes were decreasing day by day. The tree couldn't survive due to lack of rainfall, excess salinity, the heat so honey was decreasing day by day. River, canals were losing depth due to siltation, as a result, breeding and feeding ground was hampered. The prevalence of higher poverty in these areas might also be connected to poor livelihood patterns alongside higher environmental adversity. Livelihoods in these areas were mainly based on local resources (e.g. forest) and their extraction (e.g. agriculture, fishing $)^{29}$. 


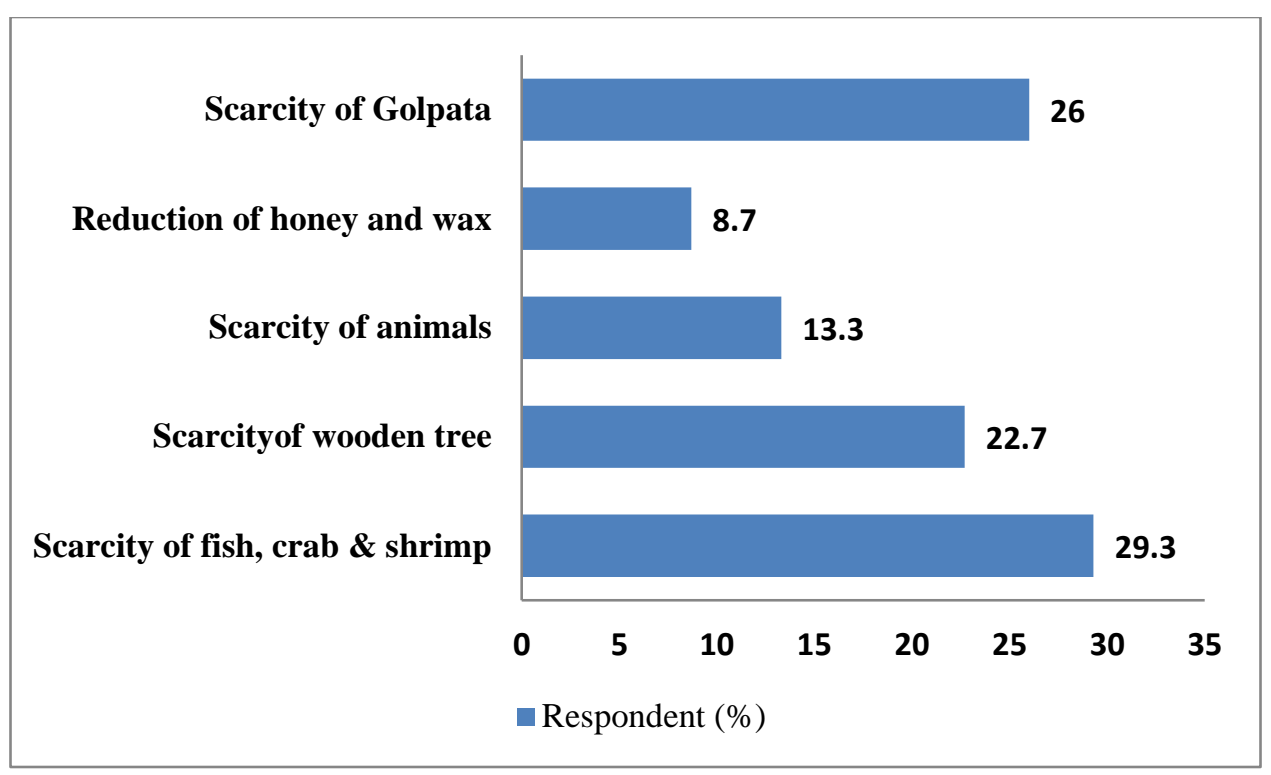

Fig. 05. Resources of the Sundarbans with the increasing impact of climate change.

\subsection{Impact of climate change on water body}

Most of the people (37\%) cited that scarcity of fish, 37\% opined siltation, and 17\% mentioned the increase of salinity and 9\% reported reduction of current as of the climate change impact (Figure 6). Rivers, canals, swamps lost their flow, and day by day fish and other aquatic animals lost their number and abundance significantly. Saline water entered into the freshwater canals. Siltation was a great problem for rivers, canals, swamps which caused floods during the rainy season. Flowing water in the rivers, canals, etc. through and around the Sundarbans flushed out saline water intrusion from the sea. Increasing salinity intrusion due to anticipated sea-level rise was one of the major threats to the Sundari trees, which were already under threat due to increased salinity levels ${ }^{30}$. 


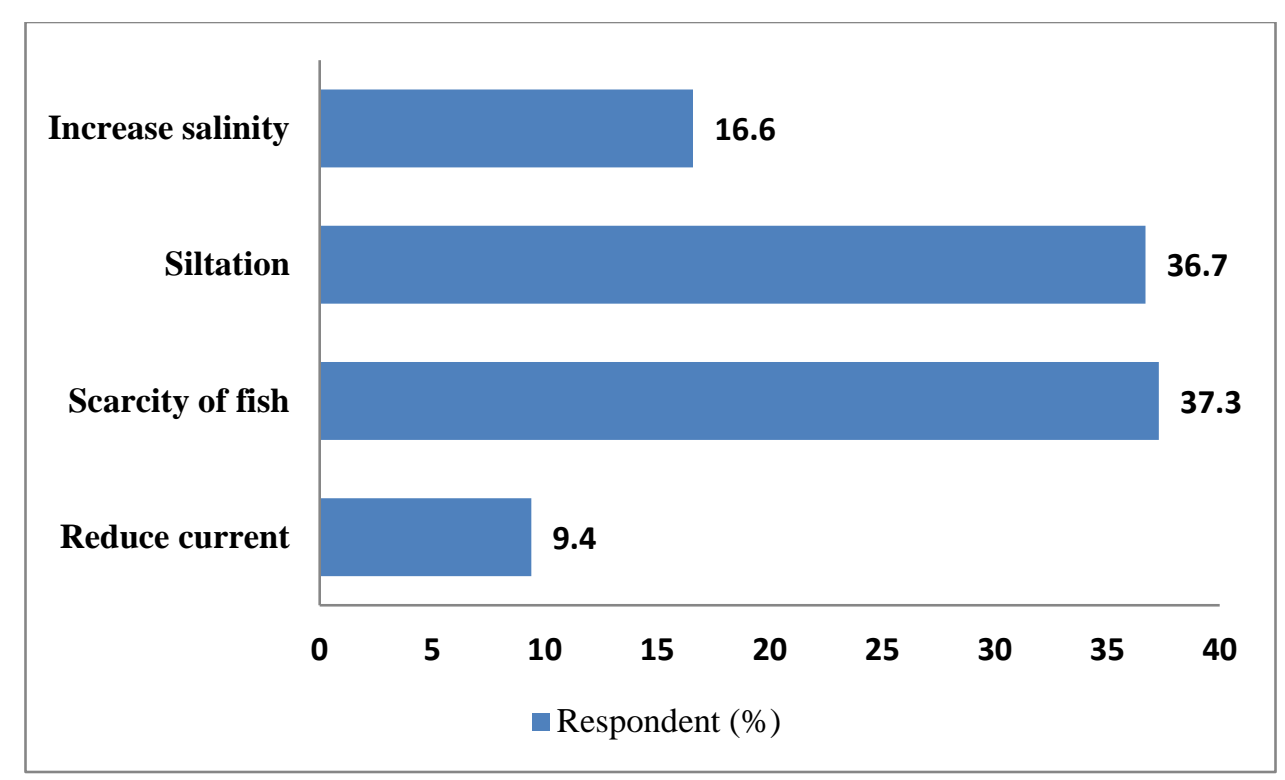

Fig. 06. Impact of climate change on the waterbody.

\subsection{Climate change impact in Agriculture}

The study showed that $38 \%$ of people said reduced yield than before, $33 \%$ people said that agricultural crops are more affected by disease and $29 \%$ said that increased soil salinity (Figure 7) . At present, salinity in river water had exacerbated the inundation problems from Cyclone Aila. The tidal surge during the cyclone rushed over or broke rivers' embankments and covered farmland in saline water. This means that even after the water had subsided and the land was dry, salinity will continue to harm crop cultivation, grazing, tree growth, etc. for years ${ }^{31,40}$. Agricultural crops were attacked by disease, pesticides, and insecticide used at high doges to prevent disease, these chemicals mixed with water and polluted the water body. 


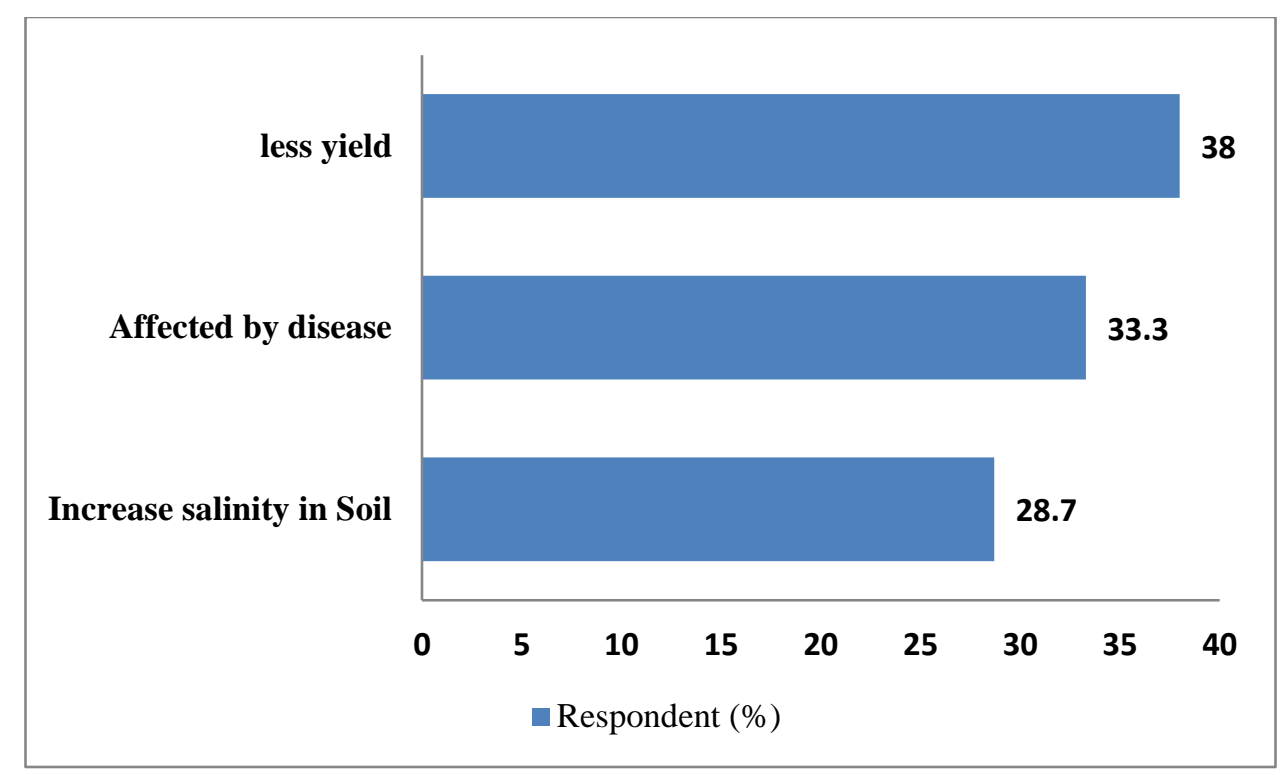

Fig. 07. Impact of climate change in agriculture.

\subsection{Climate change impact in fisheries}

The present study mentioned that, $32 \%$ of people mentioned that less production, $28 \%$ cited that affected by the disease, $24 \%$ told damage of fish farm, $9 \%$ said that loss of breeding ground and $7 \%$ loss of fishing ground (Figure 8). Climate change also affected the productivity or distribution of fishery resources of marine waters in a variety of way ${ }^{2,37}$. Changes in water temperature and precipitation affect the dynamics of ocean currents, the flow of rivers, and the area covered by wetlands ${ }^{37}$. This would have effects on ecosystem structure and function and the distribution and production of fish stocks. Increased incidence of extreme events such as floods, droughts, and storms would affect the safety and efficiency of fishing operations and increase damage and disruption to coastal and riparian homes, services and infrastructure ${ }^{32}$. Increased water temperature might likely advance the sexual maturation and the timing of spawning of adult hilsha population $^{17,18}$, this might upset timing of spawning migration into the freshwater rivers and estuarine areas $^{35}$. 


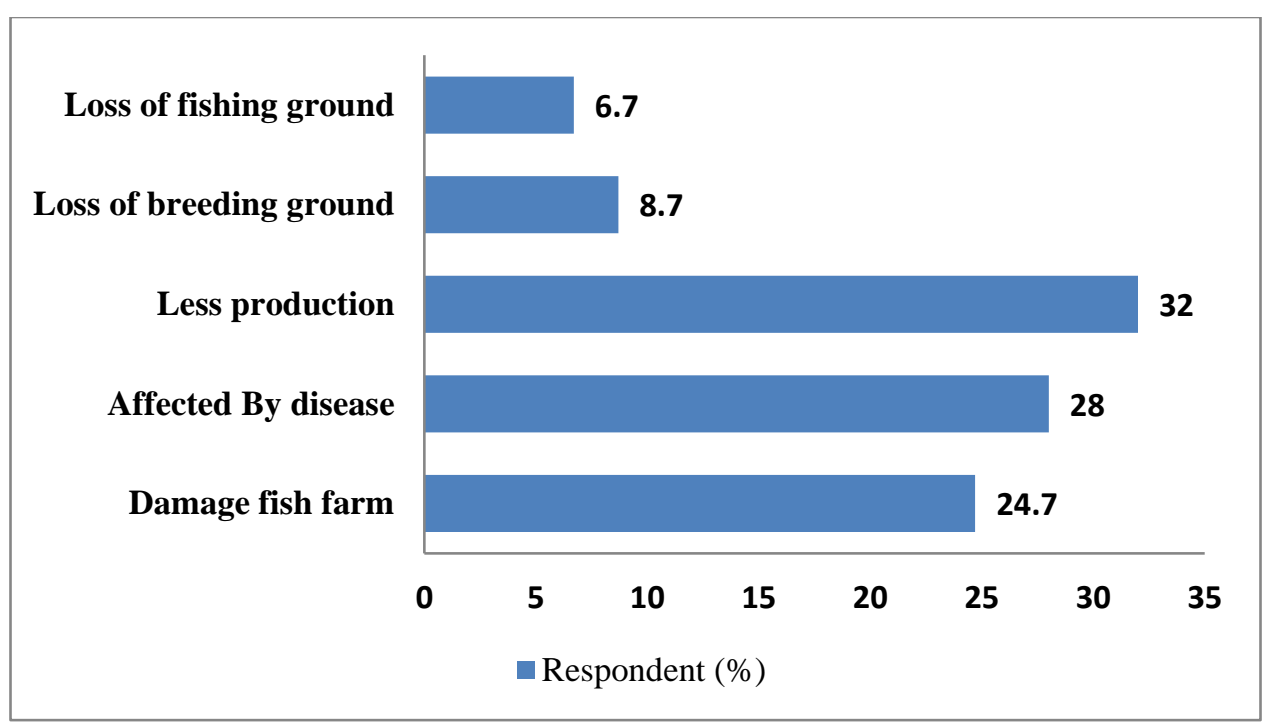

Fig. 08. Impact of climate change in fisheries.

\subsection{Status of fisherman of Sundarban}

The Sundarban dependent fishermen were decreasing (57\%), some were newly added that counted as the increase of fishermen (27\%) and 16\% remained unchanged (Figure 9). Fish availability reduced significantly due to climate change as a result fishers were decreasing day by day. Vulnerability due to climate change was influenced by the status of the community and its geographical position. As an extreme case, one fisherman mentioned during an oral history interview "during Sidr, the water [surge] suddenly came and washed away my children and my house." Fishermen mentioned in FGD that "We the fishers are more vulnerable to natural calamities as we become helpless in sudden calamities during fishing; we just remember God and our families are the worst victims as they have to live in the coastal areas". On the other hand, some fishermen engaged in fishing because they had no alternative livelihood options. A study depicts that $85 \%$ of the women in the coastal area were engaged in various works of shrimp farming ${ }^{17,42}$. Most of the women were engaged with the collection of shrimp larvae from nearby coastal rivers and marshes. The increasing salinity of river water threatened the traditional way of living in such communities ${ }^{34}$. 


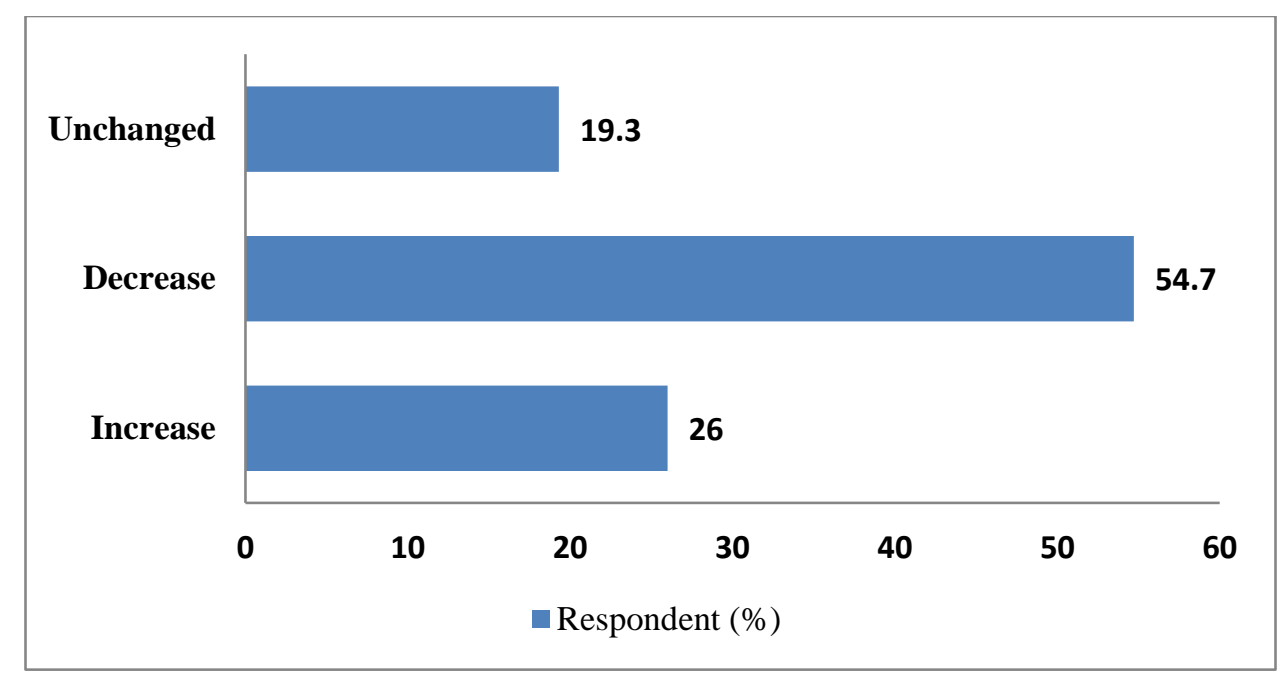

Fig. 09. Status of the fishers in the Sundarbans.

\subsection{Effect of climate change on salinity intrusion}

Among the interviewed respondents $38 \%$ said that damage of water source, $33 \%$ said that damage of cultivated land, and $29 \%$ said that losses of freshwater fishes due to salinity intrusion (Figure 10). Sea-level rise would also have adverse impacts on the forest, directly through enhanced inundation and indirectly by enhancing saline intrusion in river systems. Reduced freshwater flows coupled with sea-level rise would consequently further enhanced the dry season salinity levels in the Sundarbans ${ }^{37}$. The effects of climate change on the Sundarbans would be considerably more critical during the dry season that extends from November to April ${ }^{34,37}$.

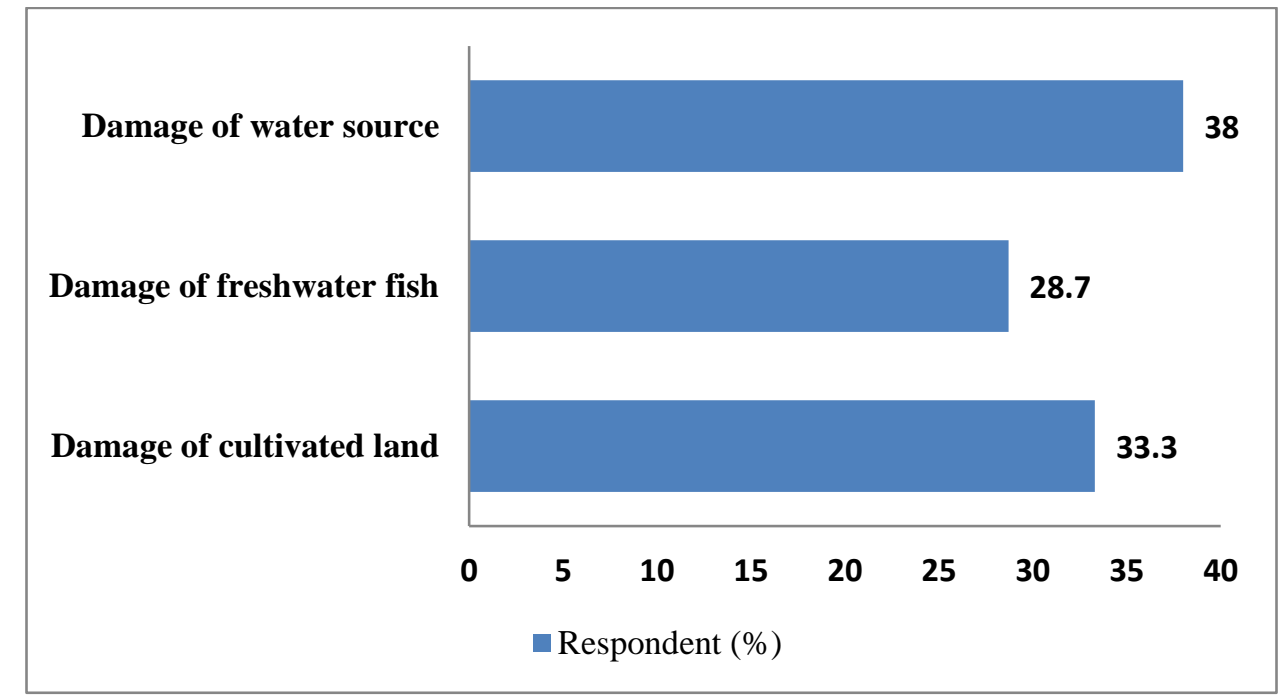

Fig. 10. Effect of climate change on salinity intrusion. 


\subsection{Occupational changes of resource users}

It was found that $14 \%$ of fishermen changed their occupation and $30 \%$ fishermen remain unchanged, $6 \%$ honey collector changed their occupation and $21 \%$ remain unchanged, $15 \%$ PL (Post-larvae) collectors changed their occupation and 20\% remain unchanged, 6\% golpata collector changed their occupation and 13\% remain unchanged, $3 \%$ woodcutters changed their occupation and 17\% remain unchanged their occupation (Figure 11). Now, 7\% respondents changed to the brick worker, $10 \%$ changed to day labor, $6 \%$ became motorcycle driver, $4 \%$ changed to construction worker, $4 \%$ became carpenter, $5 \%$ changed to patty businessman, $5 \%$ become building maker, $3 \%$ become fish farmer, 5\% become unemployed and $101 \%$ remain unchanged. Mangrove resource users changed their occupations on a large scale. Some remained unchanged. Besides these, some were newly added. The mangrove forests have been shown to sustain more than 70 direct human activities, ranging from fuel-wood collection to fisheries ${ }^{36}$.

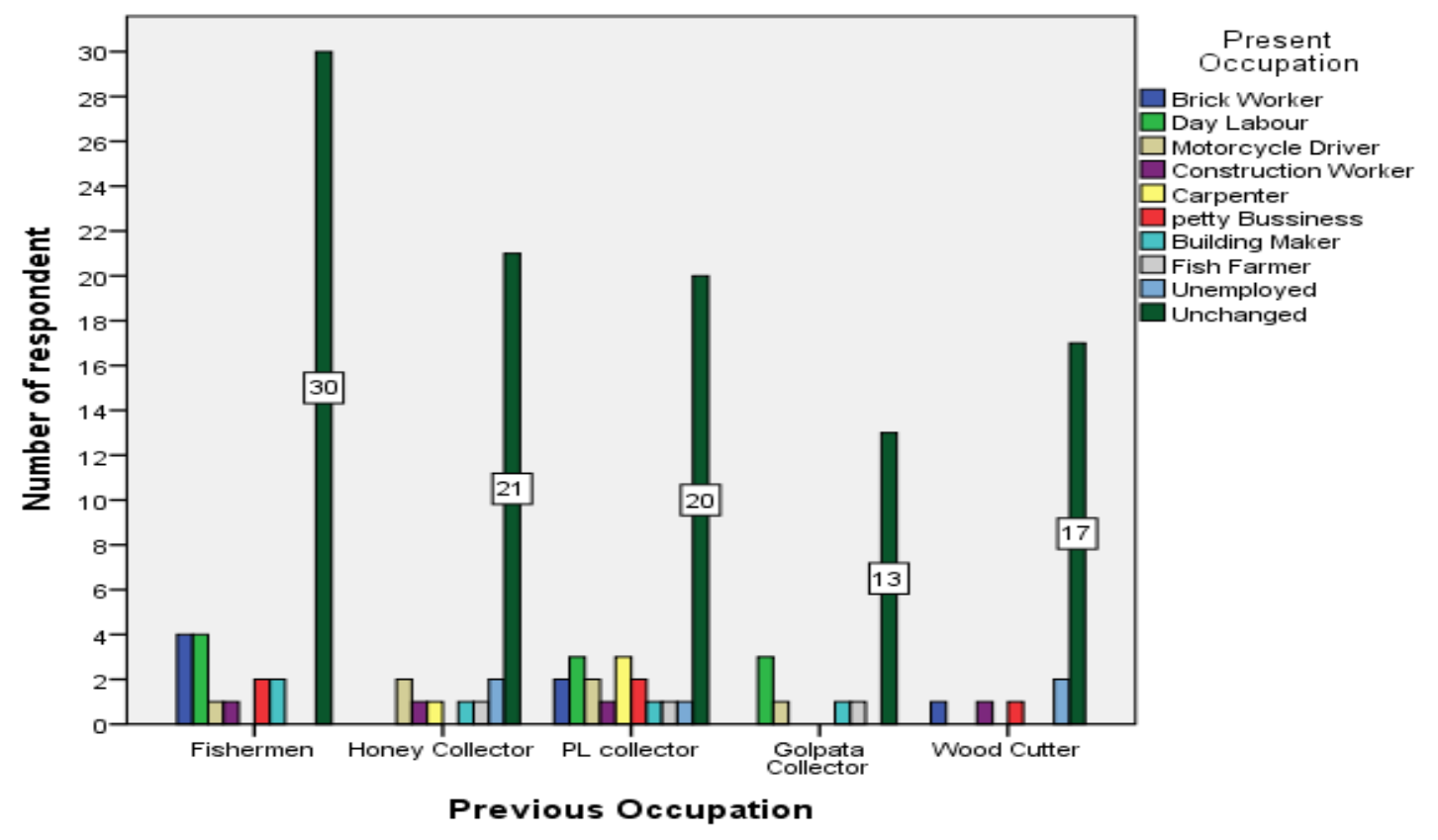

Fig.11. Occupational changes of resource users.

\subsection{Adaptation of Sundarban resource users}

The study found $29 \%$ of people change their occupation to adopt the professional loss in changing climate (Figure 12). About 3\% of people mentioned that their family members migrate towards town, $10 \%$ people tried to practice climate resilience culture techniques of rice, fish, and crops. 
About $7 \%$ of women have participated in work, homestead gardening 4\%, and salt cultivation $3 \%$. Traditional lifestyles were reasonably well adapted to these unique characteristics of the Sundarbans. Human dwellings were built on raised platforms, and farmers cultivated salinity and flood-tolerant rice during the monsoon in land protected by temporary dykes when the abundance of freshwater had greatly reduced salinity levels ${ }^{17,37,42}$.

The dykes were dismantled post-harvest, opening the land to tidal movements. Meanwhile, fishing of salt-tolerant varieties was the principal source of livelihood during the dry season when salinity levels were high. People also cultivating betel leaf as their cash crop and it was profitable. But the betel vines were very much vulnerable to flood and storm. Due to climate change, betel leaves were affected by diseases and pests. So, farmers fall into danger and became looser. Women were aware of the fact that a certain species grow well in saline conditions. They planted palm, betel nut, sofada, etc. sapling which provided little cash for the family. Women also engaged themselves in handicraft, based on their individual skill.

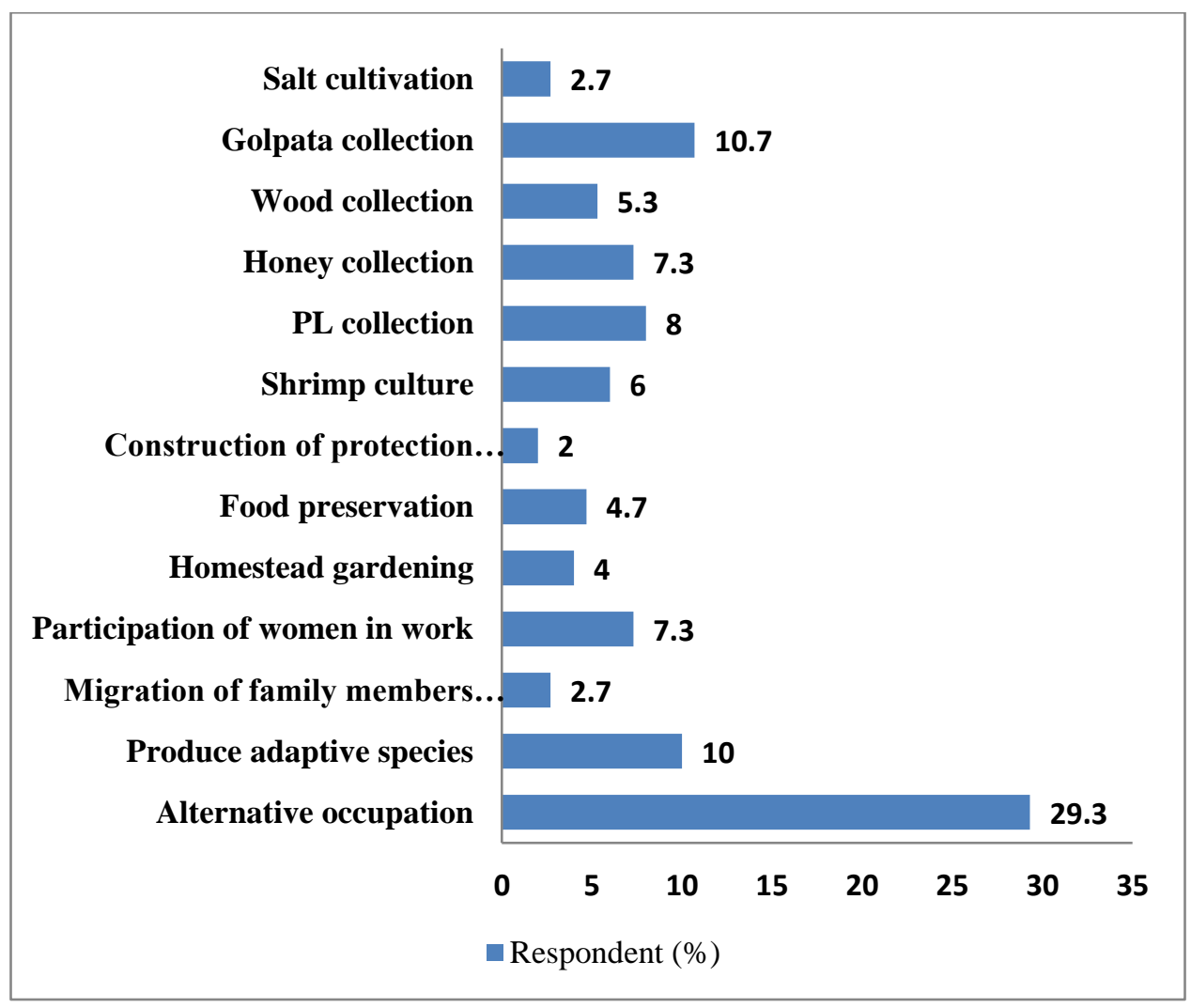

Fig.12. Adaptation mechanisms of resource users.

\subsection{Adaptation measures against climate change}


It was found that $36 \%$ of peoples took adaptation measures to cope with cyclone, $33.3 \%$ with a flood, $2 \%$ with drought, $11.3 \%$ with river erosion, and $17.4 \%$ with salinity intrusion. Flood resilient housing, raising plinth of the house was done by the flood-prone people to adapt against flood. Farmers produce saline tolerant rice such as BARI dhan 40,41, BINA Dhan 7.Chilis, Carrot, Sugar beet, Barley were also cultivated by the resource users as alternative cultivation ${ }^{26}$.

\section{Conclusion and recommendations}

Sundarbans is one of the largest mangrove forests in the world. The Sundarbans has great importance in the economy of Bangladesh but frequent occurrence of natural calamities put adverse impact on its natural resources and day-to-day life of the dependent communities. Day by day sea level raises gradually and salinity increases rapidly, as a result, cropping pattern, methods of cultivation, and variety are changed. The breeding of fish, birds, animals is hampered and the mortality rate become high. The resource users of the Sundarbans become jobless and their livelihood goes in danger in every dimension. So, it is evident that the impact of the phenomena of climate change is incredibly destructive in coastal mangrove areas. Thus, climate-associated loss should be mitigated and the rehabilitation process should follow the perceptions of the local community. Community-based resource management could improve the situation with the help of different government organizations, NGOs, and donor organizations. The findings of the study could become a guideline for better planning regarding the climate-vulnerable Sundarbans and the development of the livelihood of dependent communities. The following specific recommendations could play an important role to improve the climate resilience of the resource users of the Sundarbans mangrove forest.

- Awareness on climate change should be increased among the resource users by enhancing coordination between private and public organizations.

- Expansion of indigenous knowledge on adaptation among the climate-vulnerable communities.

- More pragmatic participation of GO's and NGO's in disaster-prone area should be ensured.

- The social security of local people should be strengthened.

- The sustainable harvest of resources should be monitored.

- More cyclone shelters, medical centers, embankments should be constructed for the security of the local people. 
- Ban of Pl collection and alternative livelihood programs should be introduced.

\section{References}

1. Alexander, C. (2014). After oil spill in Bangladesh's unique mangrove forest, fears about rare animals. Retrieved 29 July 2015.

2. Sunny, A.R. 2017. Impact of oil Spill in the Bangladesh Sundarbans. International Journal of Fisheries and Aquatic Studies, 5 (5): 365-368

3. Food and Agricultural Organization (FAO). (2007). The world's Mangroves 1980-2005, FAO Forestry Paper, 153. Retrieved from: http://www.fao.org/3/a-a1427e.pdf.

4. Mondal, M.S.H. (2015). Land covers change, population dynamics and climate change: spatial and chronological transformation of Sundarbans and its adjacent areas, Bangladesh. Master's thesis Department of Social Relations, East West University. Dhaka, Bangladesh.

5. Hossain, S., Dearing, J.A. (2015). Recent changes in ecosystem services and human wellbeing in the Bangladesh coastal zone. Springer. doi 10.1007/s10113-014-0748-z.

6. DoF. (Department of Fisheries). (2010). Integrated resources management plans for the Sundarbans. Forest Department, Ministry of Environment and Forests, Dhaka, Bangladesh.

7. Rahman, M.R., Asaduzzaman, M. (2010). Ecology of sundarban, bangladesh. J. Sci. Foundation; 8 (1-2):35-47.

8. Swapan, M.S.H., Gavin, M. (2011). A desert in the delta: participatory assessment of changing livelihoods induced by commercial shrimp farming in southwest Bangladesh. Ocean coast management; 54:45-54.doi:10.1016/j.ocecoaman.2010.10.011.

9. Chowdhury, A.H., Mannan, M.A., Gosh, P.K., Akbar, M.A. (2014). Draft Report of the Research Impact of Oil Spillage onthe Environment of Sundarbans (World Largest Mangrove Forest) in Bangladesh. at http://ncbd.org/wp-content/uploads/2014/12/Impactof-oil-spills-on-the-Sundarbans_AHC.pdf

10. Alongi, D.M., Sasekumar, A., Tirendi, F., Trott, L., Pfitzner, J., Dixon, P.,Brunskill, G.J., (2004). Sediment accumulation and rates of carbon andnitrogen flow in mangrove forests of different age: estimates of landocean-atmosphere exchange in peninsular Malaysia. Marine Geology208, 383e402. 
11. Blasco, F., Saenger, P.,Janodet, E. (1996).Mangroves as indicators of coastal change, CATENA,Volume 27, Issues 3-4,Pages 167-178, ISSN 03418162, https://doi.org/10.1016/0341-8162(96)00013-6.

12. Sunny, A.R., Reza, J., Anas, M., Hassan, M.N., Baten, M.A., Hasan, R., Monwar, M.M., Solaimoan, H., Hossain, M.M., 2020. Biodiversity assemblages and conservation necessities of ecologically sensitive natural wetlands of north eastern Bangladesh. Indian Journal of Geo-Marine Sciences, 49 (01): 135-148

13. Islam, M.M., Islam, N., Sunny, A.R., Jentoft, S., Ullah, M.H. \&Sharifuzzaman, S.M. 2016.Fishers' perceptions of the performance of hilsa shad (Tenualosa ilisha) sanctuaries in Bangladesh. Ocean \& Coastal Management, 130:309-316. DOi 10.1016/j.ocecoaman.2016.07.003

14. Sunny, A.R., Masum,K.M.,Islam, N.,Rahman, M.,Rahman, A.,Islam, J.,Rahman,S., Ahmed, K.J., Prodhan, S.H. 2020a. Analyzing livelihood sustainability of climate vulnerable fishers: Insight from Bangladesh. Journal of Aquaculture Research and Development.11(6):593, doi: 10.35248/2155-9546.19.10.593

15. Sunny, A.R., Alam, R., Sadia, A.K., Miah, Y., Hossain, S., Mofiz, S.B., et al. 2020. Factors affecting the Biodiversity and Human Well-Being of an Ecologically Sensitive Wetland of North Eastern Bangladesh. Journal of Coastal Zone Management, 23 (1):471

16. Sunny, A.R. 2017. A review on the effect of global climate change on seaweed and seagrass. International Journal of Fisheries and Aquatic Studies, 5 (6): 19-22. NAAS Rating: 3.99, ICV-Poland: 76.37

17. Sunny, A.R., Ahamed G.S., Mithun, M.H.,Islam, M.A.,Das, B., Rahman, A., et al.2019. Livelihood Status of the Hilsa (Tenualosa ilisha) Fishers: The Case of Coastal Fishing Community of The Padma River, Bangladesh. Journal of Coastal Zone Management, 22 (2):469

18. Sunny, A.R., Hassan, M.N., Mahashin, M., Nahiduzzaman, M. 2017. Present status of hilsa shad ( Tenualosa ilisha ) in Bangladesh: A review. Journal of Entomology and Zoology Studies, 5 (6): 2099-2105.

19. Islam, M.M., Shamsuzzaman, M.M., Sunny, A.R., Islam, N. 2017. Understanding fishery conflicts in the hilsa sanctuaries of Bangladesh. In: Inter-sectoral governance of inland fisheries.Song, A.M., Bower, S.D., Onyango, P., Cooke, S.J., \&Chuenpagdee, R. (eds.) 
(pp18-31), TBTI Publication Series, St John`s, NL, Canada

20. Sunny, A.R., Islam, M.M., Rahman, M., Miah, M.Y., Mostafiz, M., Islam, N., Hossain, M.Z., Chowdhury, M.A., Islam, M.A., Keus, J.H. 2019. Cost effective aquaponics for food security and income of farming households in coastal Bangladesh. The Egyptian Journal of Aquatic Research, doi.org/10.1016/j.ejar.2019.01.003.

21. Islam, M. M.,Sallu, S.,Hubacek, K.,Paavola, J. (2013). Vulnerability offishery-based livelihoods to the impacts of climate variability andchange: insights from coastal Bangladesh. Springer. DOI10.1007/s10113-013-0487-6.

22. Alam, M.\& Laurel M. (2016). Facing Up to Climate Change in South Asia. Gatekeepers.

23. Ahmed, A. U. \&Neelormi, S. (2008). Livelihoods of coastal fishermen inperil: In search of early evidence of climate change induced adverseeffects in Bangladesh. Dhaka: Centre for Global Change.

24. Ahmed, F., Al-Amin, A.Q.,Alam,G.M., Hassan, C.H. (2012). Climate change concern to cattle feed in Bangladesh. J. Anim. Vet. Adv., 11: 1946-1953.

25. Barua, Prabal\&Chowdhury, Shahnawaz\&Sarker, Subrata. (2010). Climate change and its risk reduction by mangrove ecosystem of Bangladesh. Bangladesh Res Pub J. 4.

26. Mizan, M.R., and Bijoy, M.R. (2009). Future Direction for Bangladesh in ClimateChange Adaptation and Mitigation. Dhaka, Bangladesh.

27. Rahman, M.R. \&Asaduzzaman, M. (2013). Ecology of Sundarban, Bangladesh. Journal of Science Foundation. 8. 10.3329/jsf.v8i1-2.14618.

28. Romañach, Stephanie \&Deangelis, Donald \&Koh, Hock \& Li, Yuhong\&Teh, Su \&Sulaiman, Raja \&Zhai, Lu. (2018). Conservation and restoration of mangroves: Global status, perspectives, and prognosis. Ocean and Coastal Management. 154. 72-82. 10.1016/j.ocecoaman.2018.01.009.

29. Giri, C.(2014). Distribution and dynamics of mangrove forests of South Asia, Journal of EnvironmentalManagement, http://dx.doi.org/10.1016/j.jenvman.2014.01.020.

30. Payo, A., Mukhopadhyay, A., Hazra, S. (2016). Projected changes in area of the Sundarban mangrove forest in Bangladesh due to SLR by 2100. Climatic Change 139, 279-291. https://doi.org/10.1007/s10584-016-1769-z.

31. Lönnqvist, L. (2010). Shortcut to the frontline: supporting local NGOs on climate change inBangladesh. (Occasional Papers Series No: 50). Dhaka : PRIP Trust/INTRAC. 
32. Allison, E.H. (2005). The fisheries sector, livelihoods and poverty reduction in Easternand Southern Africa. In: Rural Livelihoods and Poverty Reduction Policies(eds: F.Ellis and H.A. Freeman). Routledge, London, pp 256-273.

33. Haq, A.K.E.(2009). An Assessment of Climate Change in Annual development Plan (ADP) ofBangladesh, cited in Hedger, M., Climate Finance in Bangladesh, Lessons for development Cooperationand Climate Finance at National Level, A Policy Brief, EDC2020, 11 March 2011.

34. Chowdhury, R. K., Maruf, B. U. and Chowdhury, A. I.(2007). Climate change would intensify river erosion inBangladesh, Impact of climate change in Banhgladesh.

35. Agrawala, S., Ota, T., Ahmed, A.U.(2003). Development and Climate Change in Bangladesh:Focus on Coastal Flooding and the Sundarbans. Organisation for Economic Co-operation andDevelopment (OECD), Paris, 70 pp.

36. Barua, Prabal\&Chowdhury, Shahnawaz\&Sarker, Subrata. (2010). Climate change and its risk reduction by mangrove ecosystem of Bangladesh. Bangladesh Res Pub J. 4.

37. Islam, M.M., Sunny, A.R., Hossain, M.M., Friess, D. (2018). Drivers of Mangrove Ecosystem Service Change in the Sundarbans of Bangladesh. Singapore Journal of tropical geography, doi:10.1111/sjtg.12241.

38. Sunny, A.R., Islam, M.M., Nahiduzzaman, M., Wahab, M.A. (2018). Coping with climate change impacts: The case of coastal fishing communities in upper Meghnahilsa sanctuary of Bangladesh. In: Babel, M.S., Haarstrick, A., Ribbe, L., Shinde, V., Dichti, N. (Eds.), Water Security in Asia: Opportunities and Challenges in the Context of Climate Change, Springer, ISBN 978-3-319-54612-4, at http://www.springer.com/us/ book/9783319546117.

39. Islam M.R., Cansse, T., Islam, M.S., Sunny, A.R. (2018). Climate change and its impacts: The case of coastal fishing communities of the Meghnariver in south central Bangladesh. International Journal of Marine and Environmental Sciences, doi: 10.5281/zendo.1474924.

40. Islam, M.M., Islam, N., Mostafiz, M., Sunny, A.R., Keus, H.J., Karim, M., Hossain, M.Z.\& Sarker, S. 2018. Balancing between livelihood and biodiversity conservation: A model study on gear selectivity for harvesting small indigenous fishes in southern Bangladesh. Zoology and Ecology, doi:10.1080/21658005.2018. 
41. Sunny, A.R., Sazzad, S.A., Prodhan, S.A., Ashrafuzzaman, M., Datta, G.C., Sarker, A.K., Rahman, M., Mithun, M.M. 2021. Assessing impacts of COVID-19 on aquatic food system and small-scale fisheries in Bangladesh, Marine Policy, 126 (2021):104422 doi:10.1016/j.marpol.2021.104422

42. Sunny, A.R.; Prodhan, S.H.; Ashrafuzzaman, M.; Sazzad, S.A.; Mithun, M.H.; Haider, K.N.; Alam, M.T. Understanding Livelihood Characteristics and Vulnerabilities of Smallscale Fishers in Coastal Bangladesh. Preprints 2020, 2020060303 (doi: 10.20944/preprints202006.0303.v1). 